\title{
Land Resource Management as the Ground for Mining Area Sustainable Development
}

\author{
Aleksander Solovitskiy ${ }^{1}$, Olga Brel $^{1 *}$, Nikolai Nikulin ${ }^{1}$, Ekaterina Nastavko ${ }^{1}$, and \\ Tatayna Meser ${ }^{1}$ \\ ${ }^{1}$ Kemerovo State University, Department of Geology and Geography, 650000, Kemerovo, Krasnaya \\ Street, 6, Russia
}

\begin{abstract}
It is established that the problem of sustainable development of Kuzbass cities is their being tied to a single production and income from other sources is not considered. Therefore, their economy is underdeveloped, depends entirely on one city-forming enterprise (singleindustry city), which causes response to the slightest changes in the economic situation. In Kuzbass, all cities, except Kemerovo, are monodependent, including Kiselevsk, which economy mainly consists of coal mining enterprises. In the circumstances, there is a need to develop a set of measures for management the urban land, primarily aimed at ensuring the sustainable development of Kiselevsk city. The development of principles and management mechanism of the urban territory land fund determines its effectiveness. Establishing the dependence of rational use of land resources and sustainable development characterizes a new level of information interaction between sciences (land management and economy). Practical use of this theory is to overcome the mono-urban development of mining cities, taking into account effective subsoil management.
\end{abstract}

\section{Introduction}

In the typical Russian mining area - old industrial coal town Kiselevsk (Kemerovo region, Western Siberia, Russia) - the urgency and priority in solving the issues of urban land use are related to the specificity of settlement land that is characterized by multifunction and concentrated industrial and residential buildings. The mechanism of management and disposal of the lands of mining regions in Russia is based on the expansion of the authority of local government, the introduction of payment for land use, close connection of land management and urban development [1-2]. The absence of such mechanism at the end of the last century [3-5] in the city led to the negative consequences: the closure of six mines, the mine construction trust, three ore-processing plants, two mine-building departments; decreasing the volume of production of machine-building, chemical, food and timber manufacturing industries by $30 \%-40 \%$. The special negative impact of mining on the neighbor towns comes from water resources pollution by mines and open pits [6-8]. Due to the lack of product competitiveness at a number of machine-building and consumer goods industry enterprises, as well as the reduction of consumer demand, whole production was suspended

*Corresponding author: brel o a@mail.ru 
(Kuzbassobuv, Gormash plant). This period was characterized by a significant dominance of the coal industry share in the overall structure of industrial production, the value of which was up to $75 \%$ (Figure 1).

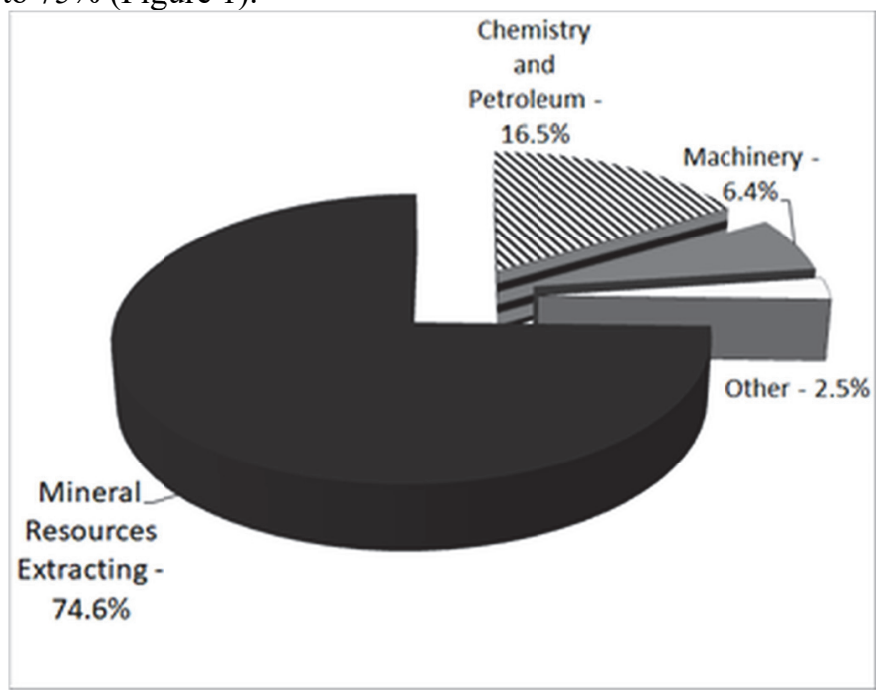

Fig. 1. The structure of production in Kiselevsk economy by industries in 2009 .

The problem of unemployment is increasing in the city. Due to the released labor force (miners) there is an increase in unemployment. Only 1.5 thousand out of 4.9 thousand workers after the closure of mines and ore-processing plants were employed. The dynamics of the unemployment rate is shown in Figure 2.

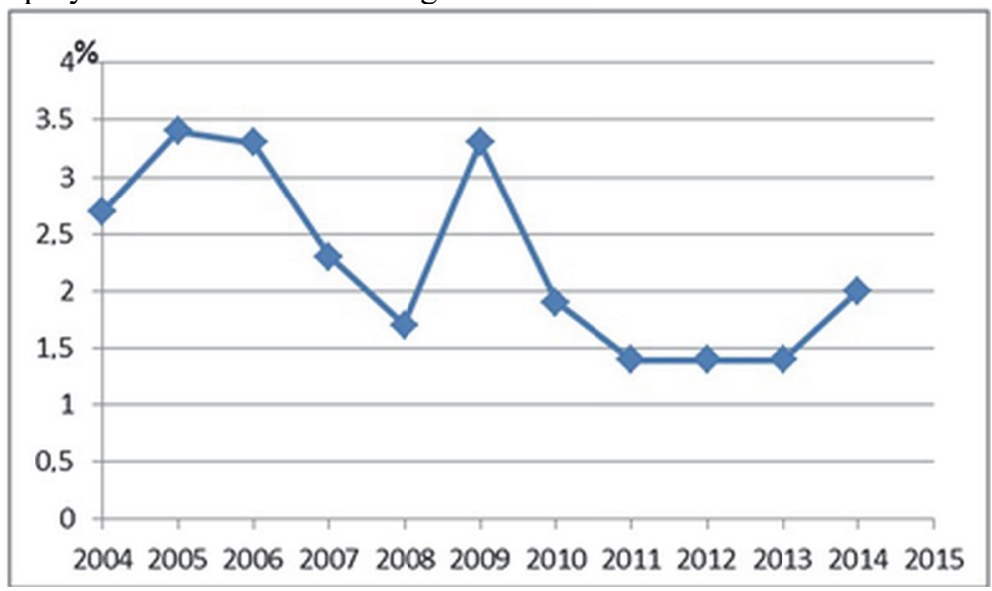

Fig. 2. The dynamics of unemployment rate ( $\%$ of the working population).

Mineral resource extracting in Kiselevsk resulted in a significant amount of disturbed land, which is about 4888 hectares (43.4\% of the total area), including 2060 hectares in open pit mining, 1550 hectares occupied by external dumps. The soil layer and underlying rocks are completely destroyed on $40 \%$ of the territory. The technogenic consequences of these enterprises operations are the following:

- air pollution caused by emissions from mining equipment, industrial and municipal boiler facilities, burning rock dumps;

- pollution of water bodies with mine, quarry, industrial and domestic wastewater;

significant disruption of the terrain; 
- exemption from land use, pollution and disturbance of land.

In Kiselevsk one of the most significant environmental problems is the work of the 4th sewerage basin. All the treated wastewater from this facility is discharged into the Akchurla River. At present, the facility's treatment equipment can not cope with the actual load, as more than $45,000 \mathrm{~m} /$ day of sewage flows, and the design capacity of the facility is less than 28 thousand $\mathrm{m} /$ day, which exceeds the norm by 1.6 times.

The foregoing indicates that keeping the dependence of the city's economy only on subsoil management does not ensure the sustainable development of Kiselevsk.

\section{Materials and Methods}

For the comprehensive modernization of urban land use in the Kiselevsky urban district within the framework of sustainable development and in order to overcome the mono-urban development [9-11], we propose the following basic principles for managing the land fund:

1. Preservation of the total area of the land fund.

2. Redistribution of the land balance to ensure revenues to budgets.

3. Improving urban area.

4. Improving the ecological situation of the territories.

In addition, we proposed a criterion for this overcoming as the initial stage of the transition to sustainable development

$$
\frac{B_{c}}{B_{a}} \leq 1
$$

where: $B_{c}$ - receipts to the budgets from coal enterprises;

$B_{a}$ - receipts to budgets from alternatively developed enterprises of other industries or businesses.

The indicated revenues to the budgets $B_{i}$ ( $i$ means $c$ for coal enterprises or $a$ for alternative) are proportional to the area of the land fund occupied by them $P_{i}$ and are the following:

$$
B_{i}=k_{i} \times C_{i} \times P_{i}
$$

where: $k_{i}$ - coefficients; $C_{i}-$ tax rates.

Proceeding from the principle of equal influence $n$ of the revenues from (1) and (2), it is easy to obtain a mathematical description of the management of the area of such an alternatively developed enterprise from other industries or business, depending on budget revenues

$$
P_{i} \geq \frac{B_{a}}{n}
$$

Based on the mentioned above, the management of the land fund includes the following main areas:

1. Changes in the type of coal mining technology on the land of the industrial zone.

2. Development of mechanical engineering and other types of industry on the lands of the industrial zone.

3. Land allotment for the development of trade and small business.

4. Land allotment for the service sector.

5. Changes in the legislation of urban land.

\section{Results and Discussion}


The management of land fund of coal enterprises is based on a change in the method of deposits development. For the effectiveness of subsoil management it is planned to develop open pit mining where the cost of a ton of produced coal is in half less than that produced by underground mining. Due to this approach the profit increases and it should be used for the own needs: technical support for the elimination of underground mining, modernization of enterprises and implementation of social programs. This management ensured the taxes revenues from mining operations to the city budget as compared to 2015 by $1.2 \%$ higher (2015 - 2433713 rubles, 2016 - 2463976 rubles).

The management of the land fund of non-coal enterprises has its own peculiarities for overcoming the mono-urban development. The following is suggested:

- the use of land fund of existing enterprises (for the machine-building complex, two enterprises (LLC «Gormash», LLC «United Machine-Building Technologies») which specialize in the production of equipment for coal and chemical industry enterprises;

- the use of adjoined territories.

For example, it is planned to build a plant for the production of mining equipment and metal structures on the territory of LLC «United Machine-Building Technologies». The effectiveness of the project includes:

- social impact (313 new jobs);

- economic effect (more than 3.5 million rubles of additional revenues to the city budget per year, an annual increase in the volume of industrial production by $3.5-4 \%$ );

- overcoming mono-urban development (reduction of the coal industry share by $3-4 \%$ ).

To implement the project it is proposed to use the existing infrastructure on an industrial site with an area of 12 hectares, where the allocation of this project is appropriate. This site has a good location (in the prospectively developing district «Red Stone») and is not far from the nearest freight railway station $(3 \mathrm{~km})$, and from the nearest KemerovoNovokuznetsk highway $(30 \mathrm{~km})$. In addition, it is planned to use an adjoined land plot of 29.2 hectares. It is characterized by the ability to connect to the entire complex of engineering networks at a sufficiently close distance, and has near railway access roads. Thus, the planned task of managing the land fund of the machine building complex is a real opportunity to attract investments for sustainable development of the city. The mechanism for its solution is the rational use of the land fund. The management of the land fund is aimed at expanding production and increasing the industrial output of the chemical industry, which is also a factor in overcoming the mono-urban development. The chemical industry of the urban district is represented by OJSC «Znamya», which employs more than a thousand people. The enterprise produces industrial explosives and is one of the main city taxpayers. In order to develop the city's chemical industry it is necessary to provide the manufacturing of new products, as well as the modernization of the production technology of industrial explosives. This management provides:

- economic effect (expansion of existing chemical production, creation of new jobs, additional revenues to the city budget of more than 3.0 million rubles a year, an increase in the output of industrial products);

- social effect (creation of new jobs);

- overcoming of mono-urban development (reduction of coal industry share by $4.5-5.5 \%$ ).

Tax revenues from the wholesale and retail trade to the municipal budget increased by $9 \%$ compared to 2015 (217,925 rubles in 2015 and 238,098 rubles in 2016). It is noted that the production of building materials in the city is not developed enough. Therefore, the task of the city authorities is to create the necessary land fund for the development of this type of production [11]. In the short term, it is planned to organize such production, as well as the development of output of related products. In connection with the opening of the oreprocessing plant, it is possible to build a factory in the city to produce silicate bricks and 
other construction materials based on ash and slag waste. This will contribute to the solution of:

- environmental problems (utilization of ash and slag waste, improvement of the ecological situation);

- economic problems (providing the Kemerovo region with affordable building materials, additional revenues to the budget of the urban district of more than 0.7 million rubles a year, an increase in industrial production by $1.5-2.5 \%$ annually);

- social problems (creating new jobs);

- overcoming the mono-urban development (reduction of the share of the coal industry by $1.5-2.5 \%)$.

Today small business provides a significant range of products. So, for example, for 2014 entrepreneurs of the urban district developed 16 investment projects $(50 \%$ in production and $50 \%$ in services). 52 jobs were created. Increasing of small and medium-sized businesses is necessary to overcome the mono-urban development. The share of tax revenues in the city budget from this type is constantly growing and reaches $16-18 \%$.

The main problems of small business and local industry development are not only related to the land fund, but also:

- project financing;

- orientation of industries;

- lack of sponsors and a narrow focus of investment activities.

The main areas of development of the land fund of small business include:

- food industry enterprises;

- consumer goods manufacturing.

Land management based on an integrated approach to sustainable development requires the creation of a transport infrastructure. Within this territory it is necessary to build new and reconstruct existing roads as well as railways. For example, it is necessary to improve the municipal bypass road in the village Uskat, as well as to coat with asphalt the constructed bypass road with the exit to the Leninsk-Kuznetsk-Novokuznetsk highway.

The tasks of road construction have been developed:

- improving the quality of the city's transport infrastructure;

- increasing the quantitative indicators of traffic;

- increasing the quality of passenger service;

- satisfaction of new transport needs;

- increasing social impact.

As part of an integrated development approach, the creation of a railway project is also proposed. On the field "Karagailinsky 1-2" it is necessary to provide the construction of private railway tracks with an adjoining to the station Uskat with a length of 1050 meters, which will allow to expand the production of this project, to optimize the costs for freight traffic.

When designing, it is necessary to ensure:

- operation stability of the railway;

- economic effect;

- obtaining maximum profit;

- improving the environment;

- quality of service.

This project requires taking into account the terrain, types of permitted use of the territory, calculation and establishment of a security zone, which is designed to ensure the safety, strength and stability of railway transport facilities. The requirements for such zones are defined by the regulatory documents (Order of the Ministry of Transport of the Russian Federation of August 6, 2008 N 126 "On approving the norms for allocation of land required for the railway rights-of-way, as well as the norms for calculating the security zone 
of the railways"). When designing the road the existing railway line from Uskat station to mine no. 12 can be used. After that, the projected road will be developed to the north to Cherepanovo village, then along the previously existing field road through the river Pryamoy Uskat and to LLC "Shahtoupravlenie Karagaylinskoye".

The world experience shows that it is possible to create parks not only on specially designated places, but also on objects that seem not only inappropriate for this, but also dangerous. There are 5 small recreation areas on the territory of Kiselevsk, but they all have a narrow focus. Multifunctional parks are a relatively new type of Public Park, which includes mass cultural and recreational, physical, and children's recreation zones, as well as a walking and economic zone. For example, it is proposed to build a new park on the territory of the former industrial enterprise the Kiselevskaya mine located in the city.

\section{Conclusions}

Based on the study results the authors developed a theory that determines the basis of managing the land fund of mining towns, and the following conclusions were made:

1. It is established that the creation of cities in the Kemerovo region on the basis of the city-forming coal enterprises does not contribute to the sustainable development of the territories.

2. It is justified that one of the first stages of sustainable development of the mining city Kiselevsk is to overcome the mono-urban development.

3. An economic mechanism for managing the land fund of a mining city has been developed to overcome the mono-urban development.

4. It is shown that a multidimensional program has been developed to ensure sustainable development. Its implementation is effective and shows positive results. The planned measures will allow reducing the coal industry share in the overall structure of the city economy to $46 \%$, which will allow eliminating the majority of risks, first of all, unmanageable transfer into managed ones to ensure further sustainable development of Kiselevsk.

\section{References}

1. M.A. Tyulenev, T.N. Gvozdkova, S.A. Zhironkin, E.A. Garina, Geotech. Geol. Eng., 35:1, 203-212 (2017)

2. T. Gvozdkova, E. Kuznetsov, A. Rudakova, S. Markov, E3S Web of Conf., 15, 01008 (2017)

3. H. Gans, Urbanism and suburbanism as ways of life: A reevaluation of definitions (Columbia University Press and Russel Sage Foundation, New York, 1991)

4. H. Molotch, Amer. J. Sociol. 82:2, 309-332 (1976)

5. R. Park, Human communities; the city and human ecology (Free Press, Glencoe, 1952)

6. M. Tyulenev, Y. Lesin, , E.Tyuleneva, , E. Murko, E3S Web of Conf., 15, 02003 (2017)

7. M. Tyulenev, E. Garina, A. Khoreshok, O. Litvin, Y. Litvin, E. Maliukhina, IOP Conf. Ser.: Earth Environ. Sci., 50:1, 012035 (2017)

8. M. Cehlár, P. Varga, Z. Jurkasová, M. Pašková, Acta Montanistica Slovaca, 15:2, 132138 (2011)

9. Shrinking cities, Urb. Des. Int. 18:1 (2013)

10. Eur. Plan. Stud. 23:1 (2015)

11. A. Haase, D. Rink, K. Grossmann, M. Bernt, V. Mykhnenko, Env. Plan. 46, 15191534 (2014) 